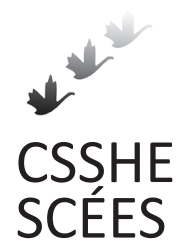

Canadian Journal of Higher Education Revue canadienne d'enseignement supérieur

Volume 42, No. 2, 2012, pages 67-78

\title{
Disenchantment and the Liberal Arts
}

\author{
Robin Lathangue \\ Trent University \\ Sacred Heart College
}

\begin{abstract}
This paper is an enquiry into the unpredictability of the liberally educated mind. We are all familiar with the value placed on the word critical when it figures prominently in justifications for liberal arts pedagogy, as in "a liberal arts education should foster the capacity for critical thinking." However, depending on the milieu in which "critical thinking" is habituated, the meaning of the term may degrade into a theoretical conformity and passive assent to established routines which are inevitably expressions of disapproval. This trajectory is described as disenchantment. Its origins are traced to representations of the intellectual as a distinctly secular creature and, in contemporary philosophical developments, associated with political liberalism-both of which, it is argued, are dominated by fear. Drawing on the recent Catholic "Communio" theology of David Schindler as a way to unveil the repressed theologies and hidden ontologies of liberal neutrality, the paper concludes with a brief examination of liberal arts scholarship that is increasingly open to various models of enchantment.
\end{abstract}

\section{RÉSUMÉ}

Cet article se veut une interrogation quant à l'imprévisibilité de l'esprit ayant reçu une formation en arts libéraux. Nous connaissons tous la valeur accordée au terme critique lorsqu'il apparait de manière saillante dans des justifications pour la pédagogie des arts libéraux, comme dans l'affirmation suivante : «Une formation en arts libéraux doit nourrir la pensée critique. » Toutefois, selon le milieu auquel la " pensée critique » s'est accoutumée, la signification du terme peut se dégrader en une conformité théorique et en un consentement passif envers les routines établies, qui sont inévitablement des expressions de désapprobation. On décrit cette trajectoire par le terme désenchantement. On retrace ses origines aux représentations de l'intellectuel en une créature 
distinctement séculaire et, avec les progrès de la philosophie contemporaine, on l'associe aujourd'hui au libéralisme politique, certains affirmant que tous deux sont dominés par la peur. Décrivant la récente théologie catholique du « communio » de David Schindler comme une façon de dévoiler les théologies refoulées et les ontologies dissimulées de la neutralité libérale, l'auteur conclut en examinant brièvement les bourses remises en arts libéraux, de plus en plus ouvertes aux différents modèles d'enchantement.

In December 2005, the Council of Ontario Universities formally endorsed "Guidelines for University Undergraduate Degree Level Expectations," a document in which the word critical appears six times-as a modifier, adjective, or adverb-and each time indicating the capacity for discernment and the analytical evaluation of something (Ontario Council of Academic Vice-Presidents, 2005). I argue that, depending on the milieu in which critical thinking is habituated, its meaning degrades into a theoretical conformity and passive assent to established routines which are inevitably expressions of disapproval. I describe this trajectory as disenchantment within liberal arts teaching and learning, and what follows is intended to trace this tendency to its roots in representations of the intellectual as a distinctly secular creature, and in contemporary philosophical developments associated with political liberalism, both of which I claim are dominated by fear. I draw on recent Catholic Communio thought as a way to unveil the repressed theologies and hidden ontologies of liberal neutrality, and I conclude with a brief examination of liberal arts scholarship that is increasingly open to various models of enchantment. Above all, I am trying to find ways of conceiving of the experience of teaching and learning as desirable enchantment, and of celebrating the unpredictability of the liberally educated mind.

\section{PART 1}

"No creature can learn that which his heart has no shape to hold," (McCarthy, 1992, p. 111) says the novelist Cormac McCarthy, reminding us that learning is a process of character. The symmetry at work - the idea that what you know depends on who you aremeans that becoming a member of a community of practice like a university involves developing a new, social self. There is reciprocity here, however, and the social identity under development shapes what one comes to know, and how we assimilate knowledge and information. Jerome Bruner makes the distinction between learning about and learning to be. But even when we learn about, in Bruner's terms, the identity we are developing determines what we pay attention to and what we learn (Brown \& Duguid, 2000).

By third or fourth year, some undergraduates in the liberal arts will feel sufficiently seasoned and confident enough in their identities as new scholars to submit their work to an essay contest. At Trent University, where I work, students submit work to a contest named in honour of the founding president, Professor Tom Symons. Here is an excerpt from a letter from one of the contest judges to colleagues in the Department of Canadian Studies:

My experience of reading the undergraduate essays submitted last spring for Symons Prizes in Canadian Studies was exhilarating and at the same time disquieting. It is a joy to see how talented and intelligent and thoughtful and articulate our 
best students are. But if these are indeed the best papers, they are similar in a way that causes me concern. They come from a wide range of disciplines and instructors, but what struck me was how common, almost universal, is our approval of negativity. It seems clear from them that we as instructors must be validating and even valorizing the discourse of grievance, objection and complaint. I think we must actively or unconsciously be encouraging suspicion and antipathy in our students. We seem to have led them to believe that being conscious means objecting to something, as if we were stuck at the stage of antithetical thought. (Johnston, personal communication, 2004)

Injustices and failures are all around us, and we must confront and engage them, correct them, and encourage students to do so as well. But how has critical thinking become synonymous with expressing disapproval? How have learners been brought to associate admiration with naïveté or treason (Johnston, personal communication, 2004)? It seems as though the disenchanting aspects of the milieu in which new students develop their new social identities effectively override whatever affirmative discourses of devotion, honour, praise, and joy they may have imported when they were admitted. In Bottom's words to Titania, "Reason and love keep little company together now-a-days; the more the pity that some honest neighbours will not make them friends" (Shakespeare, 1993, Act 3, Scene 1).

Elaine Marks, first chair of the Women's Studies Research Center and chair of Women's Studies at the University of Wisconsin-Madison, relates a teaching experience in which both her choice of certain texts and the manner of reading them were contested by students. The text was Dust Tracks on a Road by Zora Neal Hurston, assigned in a women's studies course called Writing Women's Li(v)es. What disturbed members of the all-female class (especially the white students) was that Hurston's story did not narrate the unrelieved oppression of a black woman growing up in the American south in the late 19th and early 20th centuries:

These angry students did not react with "surprise" at the discrepancy between their expectations and the words of the text but rather with hostility, in part because, through no fault of their own, they have had little or no training in the reading of a literary text. Like most readers, they tend to read uniquely for information, for historical or psychological "realism." Although the first text we had read together in that course was Nelly Furman's superb 1980 essay “Textual Feminism,” which insists on the importance of words, language, and the signifier and attempts to show that literature has functions other than the referential, their habits of reading were not easily challenged. Indeed, these habits are often supported by ideological positions that students, in some of their classes, are taught to look for in all the texts they read. If the students do not find evidence of racism, sexism, or anti-Semitism, they tend to assume that either the writer or the teacher is guilty of a cover-up. (2005, p. 422-423)

The problem is particularly acute in the liberal arts and social sciences where "aggressive vocabularies of subversion, demystification, transgression, violence, fissure, decentered subjects, fragmentation, and dismantling master narratives" are generating a "pervasive mindset" determined to wage a predictably anti-establishment ideological po- 
litical struggle (Patai \& Corral, 2005). This approach invariably ends at the same point: "A denunciation of authors for their limitations vis-à-vis the orthodoxies of the historical moment and its preferred 'voices,' or alternatively, a celebration of authors or texts for expressing the favoured politics or for merely embodying the requisite identity" (Patai \& Corral, 2005).

Behind all this ordained transgression is an image of what academic labour in the liberal arts entails:

Contemporary academics see themselves as having merely four brief years in which to demystify students, and somehow to get them to look up... long enough to gaze upon the darker side of American and Western life.... How can they make them understand, with only four years to do so, that capitalism and individualism have created cultures that are cruel, inefficient, racist, sexist, and homophobic, with oppressive caste systems, mental and behavioral? How, in such a brief period, can they enlighten "minorities," including women (the majority of students), about the "internalization" of their oppression (today's equivalent of false consciousness)? How, in only eight semesters, might they use the classroom, curriculum, and university in loco parentis to create a radical leadership among what they see as the victim groups of our society? (Kors, 2008, para. 10)

Imagine if universities actually published a clear statement of their intention to reform, setting down on page one of their academic calendars and fundraising letters:

This University believes that your sons and daughters are the racist, sexist, homophobic, Eurocentric progeny or victims of an oppressive society from which most of them received unjust privilege. In return for tuition and massive taxpayer subsidy, we shall assign rights on a compensatory basis and undertake by coercion their moral and political enlightenment. (Kors, 2008, para. 13)

Now, there are limits to parents' readiness to know, and this kind of calendar copy is "too much information." It will never see the light of day in university view-books, because if it did, the taxpayers involved would be very unhappy. It is more acceptable to say, with Edward Said (1994), that "the purpose of the intellectual's activity is to advance human freedom and knowledge" (p. 17). And yet, as literary exemplars Said offers the provocative figures of Bazarov from Turgenev's Fathers and Sons, and Stephen Dedalus from Joyce's Portrait of the Artist as a Young Man. Bazarov's is a deeply confrontational intellect, "not fit for domestication," and precisely because Dedalus is an intellectual, he "will not adjust to domesticity or to humdrum routine" (p. 17). So much for the trenches of day-to-day existence that make up much of adult life, and generate the income that goes to pay tuition.

According to a recent essay in Harper's Magazine, we should nurture and protect the liberal arts:

Why? Because they complicate our vision, pull our most cherished notions out by the roots, flay our pieties. Because they grow uncertainty. Because they expand the reach of our understanding (and therefore our compassion), even as they force us to draw and redraw the borders of tolerance. Because out of all this work of self- 
building might emerge an individual capable of humility in the face of complexity; an individual formed through questioning and therefore not likely to cede that right; an individual resistant to coercion, to manipulation and demagoguery in all their forms. (Slouka, 2009, p. 37)

We can hear in this statement the familiar justification for liberal arts education as the incubator of democratic citizenship. The point about flayed pieties should give us pause, however, as the following joke, told by David Foster Wallace in his 2005 commencement speech at Kenyon College, attempts to show:

There are these two guys sitting together in a bar in the remote Alaskan wilderness. One of the guys is religious, the other is an atheist, and the two are arguing about the existence of God with that special intensity that comes after about the fourth beer. And the atheist says: "Look, it's not like I don't have actual reasons for not believing in God. It's not like I haven't ever experimented with the whole God and prayer thing. Just last month I got caught away from the camp in that terrible blizzard, and I was totally lost and I couldn't see a thing, and it was 50 below, and so I tried it: I fell to my knees in the snow and cried out 'Oh, God, if there is a God, I'm lost in this blizzard, and I'm gonna die if you don't help me." And now, in the bar, the religious guy looks at the atheist all puzzled. "Well then you must believe now," he says. "After all, here you are, alive." The atheist just rolls his eyes. "No, man, all that was was a couple Eskimos happened to come wandering by and showed me the way back to camp." (2008, para. 4)

The atheism in this story is an illiberal dismissal of the possibility that the passing Inuit had anything to do with a prayer for help. Indeed, a truly critical thinker would reject "blind certainty," even in its atheistic mode, as "a close-mindedness that amounts to an imprisonment so total that the prisoner doesn't even know he's locked up" (Wallace, 2008, para. 5).

How, in the liberally educated mind, has the experience of faith, reverence, or devotion come to be associated with blind conformity and unreflective adherence to old ways? The answer, for Said (1994), is that the life of the mind is intrinsically non-theological: "The true intellectual is a secular being" (p. 89). Said is well known as an advocate of the form of secularism that condemns religion while also relegating it to the private sphere. For Said, "In the secular world-our world, the historical and social world made by human effort-the intellectual has only secular means to work with; revelation and inspiration, while perfectly feasible as modes of understanding in private life, are disasters and even barbaric when put to use by theoretically minded men and women. Indeed, I would go so far as saying that the intellectual must be involved in a lifelong dispute with all the guardians of sacred vision or text, whose depredations are legion and whose heavy hand brooks no disagreement and certainly no diversity" (p. 65). But there is a back story to Said's definition of intellectual activity in terms of secular criticism, the theme of which is political salvation and rescue from religious violence. 


\section{PART 2}

The politically neutral "state," a centralized power holding a monopoly on violence within a defined territory, first appeared during the anarchy that convulsed Western Europe throughout the 16th and 17th centuries (Weber, 1946). We are all familiar with the "wars of religion" and the historical narrative of how the modern state saved us from our religious selves. The liberal democratic state delivers us "from the bloodshed and brutality of religious disagreement" (Bell, 2007, p. 426). In the wake of the Reformation, as theological passion blended with political power, wars ensued and liberalism was born out of religious cruelty.

Anxieties about violence in the relations between the religions are widely shared. If Christians can treat each other so abominably, what hope is there for believers of different faiths, especially today? No surprise, then, that all the quality press in the academic study of religion and theology assumes that "religion is a prime (often the prime) source of violence, and the modern state and market the great bringer of peace" (Milbank, Pickstock, \& Ward, 1999, p. 14).

This state salvation story is rooted in modern liberal political philosophy and its courageous search for a core morality on which people with different theological reasons for living can agree. Many theorists locate their courage in terms of a thoroughly detached relation to inherited and community-based forms of felt conviction and religious cultural traditions. This line of argument calls for a philosophy of individualism in support of the principle of neutrality: the idea that the state should not promote one controversial view of the good life at the expense of others. Liberalism should be conceived as a strictly political doctrine, as distinguished from a general philosophy of humanity or a comprehensive moral doctrine. Liberal political structures, it is argued, are not the same as liberal political theory or ideology, and this distinction provides a justification for neutrality "without having to take sides in the dispute about individualism and tradition" (Larmore, 1996, p. 132).

In this view, the norms of political liberalism, especially equal respect and rational dialogue, are ranked higher than theologically-based anthropologies, and any doubt of the character of this move elicits a dire warning: To make of liberal neutrality yet another controversial and partisan vision of the good life is to disable it, and either modern experience dissolves in the light of "the one irresistible, all-encompassing Good," or our political future will be one "where ignorant armies clash by night" (p. 151). As modern experience is not likely to dissolve into beneficent universalism, there comes into view from Matthew Arnold's "Dover Beach" a fearful nightmare vision from which all educators, secular and religious, liberal or conservative, should like to awake.

Instead of trembling at this prospect, however, recent critics such as David L. Schindler and Luke Bretherton have drawn attention to how arguments for neutrality like this one furnished by political liberalism actually draw everyone into a con game. In the (putatively) neutral and open market of religious worldviews, we must also accept terms that are (hiddenly) filled out with a liberal theory of religion - a theory, by the way, that liberal theory claims not to have. The argument here is that the appeal to liberal neutrality, as regards competing visions of the good life, hides its own truth about the nature of religion. If the critics are right, then we are looking at a deceit that should be unacceptable, 
regardless of one's convictions about a transcendent order, because no matter what those convictions are, they are viewed with complete indifference by this neutral party, political liberalism. As one commentator has recently noted, what appears tolerant because it values all differences isn't tolerant at all because it refuses to engage with differences, judging all particularity as of equal value or as essentially the same (Bretherton, 2008).

While the refusal to engage appears at first as a strategic advance onto neutral common ground because it is supposed to maintain the peace when reasonable people disagree about religion, it turns out to be finesse. The empty character of neutrality actually prepares the ground for the delivery of a liberal anthropology (Schindler, 1996). If we slow liberal theory down, we see that it imports-frame by frame-both metaphysics and theology, which on the surface it claims not to do. This way of defending liberal neutrality soon collapses into a hidden atheistic dogmatism that cannot conceive of prayers being answered.

First of all, it is impossible to distinguish the formal constitutional structures (like a neutral forum of rational dialogue and equal respect, protected by the state) from liberal theory as such unless we define religious freedom primarily in negative terms-as a protection from the coercion to confess only one set of convictions. But what if religious freedom, when defined in negative terms (as freedom from), "already presupposes a theory of religion different from one which would define religious freedom first in positive terms, in terms of the person's positive relation toward God" (Schindler, 1996, p. 50)? While liberal neutrality may claim or intend a positive sense of openness to the transcendent, it is in fact a comprehensive silence about God, gods, and the transcendent order. This silence, "is not yet, in and of itself, an indication of positive openness to God" (p. 63, emphasis in original), and it is not possible to have it both ways. You cannot embrace a formal definition of political neutrality (freedom from), while implying a positive openness to the idea of God (freedom for). To insist that freedom from carries a logical implication of freedom for is to abandon the claim of political neutrality.

Thus political liberalism already serves to dispose society logically toward an "indifferent" human nature and to mute all talk of a nature positively oriented toward God (Schindler, 1996). Here is one of the more influential pictures of that indifference:

How recognizable, how familiar to us, is the man... who confronted even with Christ turns away to consider the judgment of his own conscience and to hear the voice of his own reason. Stripped of the exiguous metaphysical background... this man is with us still, free, independent, lonely, powerful, rational, responsible, brave, the hero of so many novels and books of moral philosophy.... He is the offspring of the age of science, confidently rational and yet increasingly aware of his alienation from the material universe which his discoveries reveal. (Murdoch, 1986, p. 80)

The "non-confessional state" as envisioned by political liberalism finds its correlation in precisely this anthropology: "rational, responsible, brave" (Schindler, 1996, p. 83), and-in the end-unable to avoid affirming a priority of freedom from faith or freedom for faith. In its moment of weakness, the neutrality of political liberalism tilts toward the negative (freedom from) and transforms what religious people take to be self-evident meaning their convictions. A comprehensive vision of the good becomes modular; in other words, a fungible appendix that is bolted onto human nature: 
The non-triviality of this maneuver becomes especially clear when we note its implications with respect to any non-Western (or nonliberalized) religion-with respect to any country where a traditional (or non-dualistic) worldview still predominates. In countries, for example, where certain forms of Orthodoxy, Islam, Judaism, Native American-Indian, or African religion still prevail, an invitation to adopt the juridical notion of religious freedom (freedom from) amounts to nothing less than an invitation to adopt the theological dualism of liberalism in the name of a purely formal commitment to the principle of freedom. (Schindler, 1996, p. 66-67)

That which guarantees the required neutrality turns out to be a theoretical dualism that reorients identity. In the end, critics argue that political liberalism distorts "the religiousness of religions" (McIntire, 2007, p. 11). It does not leave traditional religion intact, but instead requires its realignment in terms acceptable to the dualism of church and state (Schindler, 1996). The significance of this point becomes clear when we recall Said's notion of religion as a fundamentally private disposition of the individual. According to political liberalism, the human act, in its basic structure, is understood for the purposes of the public realm to be silent toward, or devoid of any meaningful connection to, God:

But this means that, when religious people go on to fill this silence with speech, they must do so precisely by way of addition and in their capacity as private members of society. Non-theists, in contrast, have merely to leave the state's formally conceived human act as it is, namely in the emptiness which has already been accorded official-public status. (Schindler, 1996, p. 69, emphasis in original)

Believers may balk at the demands for public atheism and atheists may find themselves with unwarranted theoretical privileges in modern liberal democracies, their public spheres, and their institutions of higher learning, but remember, according to Larmore (1996, p. 151), the consequences if we take liberalism to be only one more partisan ideal: Our future will be one "where ignorant armies clash by night."

\section{PART 3}

In Max Weber's widely acclaimed discussion of the term, disenchantment describes a world that has lost some of its allure and now seems lifeless in certain ways. But Weber was not nostalgic for the old world. He thought the process was inevitable and on the whole beneficial (Sherry, 2009, p. 369-370). To the extent that it is a loss, disenchantment is the desirable loss of error, superstition, and illusion (a disarming of ignorant armies), but as a paradigm for liberal arts, education and vocation of the intellectual disenchantment is or ought to be disintegrating. I hope I have been able to show how that might be brought about from the perspective of political theology, but scholars outside of that discipline increasingly share and promote the criticisms that reveal how the modernist secular template is anything but neutral and blank (McIntire, 2007). Some, for example, have argued that the binary approach to modernity and enchantment (where they are mutually exclusive categories) obscures tensions and contradictions intrinsic to the modern world: "The seeming 'universal' distinctions championed by the Western metropole between modernity and tradition, or secularism and superstition, often do not hold 
up... when viewed from the 'periphery' of non-Western cultures negotiating processes of modernization in complex ways" (Landy \& Saler, 2009, p. 6). In addition, teachers are increasingly appreciative of their own roles in the construction of knowledge of religion and willing to clarify how their own lived relationship with religion conditions their study of religion (McIntire, 2007).

Looking farther afield, we encounter recent evidence that the problems of modernity and enchantment are eliciting responses that explore their compatibility. According to this view, the contemporary world retains the power to enchant humans, and we can cultivate ourselves so as to experience more of its effects: "Enchantment is something that we encounter, that hits us, but it is also a comportment that can be fostered through deliberate strategies" (Bennett, 2001, p. 4). We can, in other words, put ourselves in the way of enchantment. As an example of one of these strategies the spectacle of modern sports events.

At a Stanford University colloquium in 1995, Pablo Morales, a three-time Olympic gold medallist in swimming, was quoted by Gumbrecht (2009) as saying it was the addictive qualities of "being lost in focused intensity" (p. 150) that had lured him out of retirement and back into competition. To some theorists, this view suggests that sport can become, for athletes and spectators, a strategy for re-enchantment. "Being lost" points metaphorically to the sacred, "as a realm whose fascination relies on being set apart from everyday worlds" (p. 150). "Being lost” refers to the distance and isolation an athlete feels during competition, so much so that from the perspective of mundane everyday life, athletic events are extra-ordinary. Second, what athletes and spectators focus on and follow in a game or competition belongs to the "realm of epiphanies" (p. 150). Athletic epiphanies reveal the body in motion and show moving bodies as "temporalized form." The wellturned double play in baseball, for example, has in this reading a miraculously balletic quality, full of grace, strength, and timing. A beautiful play in football "is an epiphany of form because it has its substance in the participating athletes' bodies; because the form it produces is unlikely and thereby an event, achieved against the resistance against the other team's defense; and finally and above all the beautiful play is an epiphany because it is a temporalized form, a form that begins to vanish in the very process of emergence" (p. 153). Third, whenever hockey goalies or tennis players talk of "being in the zone," we might see "halos of intensity." A player must be physically and mentally conditioned for this state to occur, but conditioning alone is not enough: "What else needs to happen for a player to be in the zone will depend, as we would say today, on whether he is 'on,' whether a specific game is 'his' or not-it will depend on what the Greeks would have called divine inspiration" (Gumbrecht, 2009, p. 152-153). Finally, there is the obvious comparison of stadiums to sacred spaces and their irresistible appeal for sports fans:

Above all, stadiums as sacred spaces are spaces that require and trigger layers of ritualized behaviour during those comparatively short moments in which they are filled with action. Being in a stadium, both for athletes and spectators, is not primarily about inventing and showing individualized action. It is about inscribing oneself, physically, into a pre-existing order that only allows for narrow spaces of variation. Every event, every country, every moment in the history of sport devel- 
ops its own rituals, poses, and gestures that open up a dimension for endless individual interpretation. (Gumbrecht, 2009, p. 155)

Spectators, too, feel something special when they enter a soccer stadium shortly before kickoff: They see and are immediately attracted to the empty space, and they wait in anticipation for the players to enter from the tunnels. Then, "it is through the utterly unsurprising and yet explosively exciting moment when the teams take the field that the spectators are conjured into their communal identity and agency" (Gumbrecht, 2009, p. 155).

\section{CONCLUSION}

This analysis takes us to the gratitude many sports fans feel toward their most admired heroes. I admire third baseman David Wright of the New York Mets, but chances are I will never have an opportunity to express my admiration to him personally or in conversation. So, in an age where the traditional religious horizons appear to have receded out of sight, my gratitude gets deflected toward the world that we have:

Gratitude for great athletic moments turns into gratitude for those things that we approve of, like, enjoy, and appreciate in our everyday lives. Being thankful for what we have does not necessarily make us "uncritical" and "affirmative." Although this exactly must be a fear that explains why so many intellectuals-even some intellectuals who love to watch or to practice sport-have such a hard time making peace with it. (Gumbrecht, 2009, p. 158)

The academic world in which we live and work is steeped in the tradition of sic et non, of a dialectic originating in Aristotelian logic, of debating clubs in which you are only able to say something by confronting the opposition, and by taking an adversarial stance (Johnston, personal communication, 2004). It is indeed remarkable how ferocious the competitive instinct can be in all quarters of academia. What I have argued here is that non is swamping sic these days, that the problem at its core involves representations of the intellectual in liberal democracy as a figure dominated by fear, and that the negative discourse is inordinately consuming us.

Here is one of the many ways allusions to our times as the "age of anxiety" (Auden, 2011) seem to hit home. In a recent essay, continental philosopher Slavoj Žižek (2005) suggests that what causes anxiety is the transformation of transgression into the norm: "Since, even before we can assert our singularity through our resistance to the norm, the norm in advance enjoins us to resist, to violate, to go further and further" (p. 69). Inherited reverences as norms governing personal and social interactions no longer function as they once did; the reality is they no longer serve anyone as warnings or paradigms. Instead, they facilitate transgressive behaviours:

These regulations no longer function as the symbolic prohibition-they rather regulate modes of transgression themselves. So when the ruling ideology enjoins us to enjoy sex, not to feel guilty about it, since we are not bound by any prohibitions whose violations should make us feel guilty, the price we pay for this absence of guilt is anxiety. (Žižek, 2005, p. 69) 
Here, then, is the intimation of deprival as far as teaching and learning goes. If, even before they can assert a singularity through resistance to norms and reverences, learners are encouraged in advance to resist, to violate, to go further and further, then we suck the air out of the "breathing space" provided by reverences and prohibitions (Žižek, 2005, p. 69). To deny learners the experience of limits that allow for safe return from risky behaviours that are not yet fully transgressive (that is, breathing space), and instead to furnish only opportunities for them to flay their own and others' pieties directly, is suffocating. It says not only that we teach from a position of fear, but that we offer existential anxiety as proof of success. In the liberal arts, it is difficult to conceive of a more egregious disservice.*

\section{REFERENCES}

Auden, W. H. (2011). The age of anxiety: A baroque eclogue. Princeton, NJ: Princeton University Press.

Bell, D. M., Jr. (2007). State and civil society. In P. Scott \& W. T. Cavanaugh (Eds.), The Blackwell companion to political theology (pp. 423-438). Malden, Oxford, \& Carlton: Blackwell Publishing.

Bennett, J. (2001). The enchantment of modern life: Attachments, crossings, and ethics. Princeton \& Oxford: Princeton University Press.

Bretherton, L. (2008). Review of the book Theology, political theory and pluralism: Beyond tolerance and difference, by K. Deede Johnson. The Journal of the American Academy of Religion, 76(I), 171-172.

Brown, J. S., \& Duguid, P. (2000). The social life of information. Boston: Harvard Business School Press.

Gumbrecht, H. U. (2009). "Lost in focused intensity": Spectator sports and strategies of re-enchantment. In J. Landy \& M. Saler (Eds.), The re-enchantment of the world: Secular magic in a rational age (pp. 149-158). Stanford: Stanford University Press.

Kors, A. C. (2008). On the sadness of higher education. The New Criterion, 26(May). Retrieved from http://www.newcriterion.com/articles.cfm/On-the-sadness-of-highereducation-3831

Landy, J., \& Saler, M. (Eds.). (2009). The re-enchantment of the world: Secular magic in a rational age. Stanford: Stanford University Press.

Larmore, C. (1996). The morals of modernity. Cambridge: Cambridge University Press.

Marks, E. (2005). Feminism's perverse effects. In D. Patai \& W. H. Corral (Eds.), Theory's empire: An anthology of dissent (p. 419-424). New York: Columbia University Press.

McCarthy, C. (1992). All the pretty horses. New York: Vintage Books.

McIntire, C. T. (2007). How religious studies misunderstands religion. Academic Matters, December/Décembre, 9-13.

Milbank, J., Pickstock, C., \& Ward, G. (Eds.) (1999). Radical orthodoxy: A new theology. London: Routledge. 
Murdoch, I. (1986). The sovereignty of good. London: Routledge \& Kegan Paul.

Ontario Council of Academic Vice-Presidents. (2005). Guidelines for university undergraduate degree level expectations. The University of Western Ontario Handbook of Academic Scholarship and Policy. Retrieved from http://www.uwo.ca/univsec/ handbook/general/OCAV_Guidelines_2005.pdf

Patai, D., \& Corral, W. H. (2005). Theory's empire: An anthology of dissent. New York: Columbia University Press.

Said, E. W. (1994). Representations of the intellectual. London: Vintage Books.

Schindler, D. L. (1996). Heart of the world, center of the church: Communio ecclesiology, liberalism, and liberation. Grand Rapids: Wm. B. Eerdmans Publishing.

Shakespeare, W. (1993). A midsummer night's dream. The complete works of William Shakespeare. Retrieved from http://shakespeare.mit.edu/midsummer/ midsummer.3.1.html

Sherry, P. (2009). Disenchantment, re-enchantment, and enchantment. Modern Theology, 25(3), 369-386.

Slouka, M. (2009). When math and science rule the school. Harper's Magazine (319), September, 32-40.

Wallace, D. F. (2008). In memoriam. The economist: More intelligent life. Retrieved from http://moreintelligentlife.com/story/david-foster-wallace-in-his-own-words

Weber, M. (1946). Politics as a vocation. In H. H. Gerth \& C. Wright Mills (Trans. \& Eds.), From Max Weber: Essays on sociology. New York: Oxford University Press.

Žižek, S. (2005). The "thrilling romance of orthodoxy. In C. Davis, J. Milbank, \& S. Žižek (Eds.), Theology and the political: The new debate. Durham \& London: Duke University Press.

\section{CONTACT INFORMATION}

Robin Lathangue

Dean of Studies, Sacred Heart College, Peterborough Ontario

dean@sacredheartofpeterborough.org

Robin Lathangue taught political philosophy, contemporary studies, religious studies, and leadership at St. Thomas and Wilfrid Laurier Universities. He worked in extension and community engagement at the University of New Brunswick and the University of Alberta. He is currently Dean of Studies and Professor of Ethics and Leadership at Sacred Heart College in Peterborough. He has published numerous articles on contemporary philosophy, religion, and culture in Arena Journal, Topia: Canadian Journal of Cultural Studies, and the Southern Journal of Philosophy. 